\title{
Governmental Communication Strategies in Socializing Waste Management
}

\author{
Armawati Arbi
}

\begin{abstract}
It is not a guarantee that a higher budget for South Tangsel government will result in better waste management in Pamulang. South Tangerang government as senders should reach many different audiences, from the highest hierarchy in formal and informal forms to the lowest government, such as in an RT (neighborhood group) or RW (community group) on the grassroots level. On the kelurahan (administrative village) level, various media tactics have not yet been used to deal with crucial issues such as air pollution, water pollution, and land pollution in legal waste disposal (Tempat Pembuangan Sementara resmi) and legal landfill (Tempat Pembuangan Akhir resmi). The communities as the receivers are not yet aware of this pollution and its effect. Apparently both the senders and receivers have their own methods for waste management. Similarly, the spiritual and environmental communication between them is also disconnected.

This paper looks at the communication strategies of South Tangerang government in socializing waste management in Bambu Apus District, Tangerang Selatan, Banten District, Indonesia. The qualitative approach, constructivism paradigm, and multi method are used to analyze the collected data. The research results present the communication strategies of the executive, legislative, and judiciary institutions of the senders. The first findings reveal that various media and non-media are applied by three institutions' strategic communication. The second finding, which covers the various meanings of audiences and the government in waste management, will be discussed in the next article.
\end{abstract}

Index Terms-Environmental communication, waste management, communication strategies.

\section{INTRODUCTION}

Legislative, executive, and judiciary institutions in South Tangerang are the senders in socializing waste management. Residents in RT (neighborhood groups) 03 and RW 01(community group) and Bambu Apus village people, Pamulang, South Tangerang, Banten Province, Indonesia, are the receivers. When messages are delivered by senders, it is assumed that receivers will understand the same message and share the same feelings about it. However, it is not always like that. We will discuss those messages that are accepted and those that are not.

To the extent of political communication, Airin Rachmi Diany---the mayor of South Tangerang, Banten province--successfully drafted her self-image and identification as one of the female candidates during the mayoral election in 2009. She promoted environmental problems as specific and

Manuscript received June 26, 2014; revised May 25, 2015.

Armawati Arbi is with Faculty of Dakwah and Communication Science, UIN Syarif Hidyatullah Jakarta, J1. Ir.H.Djuanda no.95 Ciputat, Jakarta 15419, Indonesia (e-mail armaarbi@gmail.com, and armawati.arbi@uinjkt.ac.id) crucial issues in her campaign. Nevertheless, up until the public election on April 9, 2014, she has not undertaken serious efforts in dealing with the issue of waste management through her 12 Waste Bank program. Tangsel Pos reported that Airin Rachmi Diany was surprised about how difficult it is to manage the waste in Ciputat market. The waste does not only originate from Ciputat market, but also from various communities and houses. [1] DKPP, Dinas Kebersihan Pertamanan, dan Pemakaman (The Department of Sanitation, Landscaping, and Cemetery Affairs) doesn't have enough vehicles to manage the waste.

During the general election in 2014, some male and female candidates brought up the issue of saving the earth, which involved waste management issues. Take, for example, the following: Eni, Sofyan, Bionaris from PPP Party with their Waste Bank program (Eni): PKS Party with their 3 Rs - Reduce, Recycle, Reuse program; and Gerinda Party with their waste management program (Sofyan). Another candidate from the independent party who are Go Green activists issued the clean housing program (Bionaris). Unfortunately, none of them were elected. The "green" issues were not a hot topic that year.

Tangsel Post on Tuesday, April 22, 2014 said that based on the results of the quick count, there are 32 new and 16 old members originating from the previous legislative period in the current 2014-2019 period in South Tangerang. Bambang P Rachmadi from the Demokrat Party was the chief representative of the legislative institution and Ruhamaben from the PKS Party is the vice representative of the legislative institution/budget commission [2].

We hope that the legislators have an environmental point of view or paradigm. Kahn (1993) found that compared to male candidates, women are even more likely to be serious about an issue. The content of the issues that concern men and women are as expected: "Men are more likely to discuss economic issues such as taxes and the federal budget, while women spend more time talking about social issues and social policy, such as the education and health policies [3]."

The mayor of South Tangerang and DKPP in Banten Province, Indonesia is the sender. DKPP officers established the law of waste management in 2008. Ronald Smith argued that the officer as a sender has selected the tactics and characteristics of the communication strategy, such as transfer brochures. Tactics are characterized by the following: key people, high impact, and low cost. The college view book as a tactic is characterized as having key people and high visual impact [4]. The government should be aware of any media which carries its own advantages and disadvantages. There are various kinds of media, such as printed, electronic, and new media. These tactics use organizational media to publicize their expanded program.

The same references 4, 7 (p. 155 and 174), and 9 (p.204). 
Ronald D Smith (2002, 155) also dealt with strategic communication categories. Smith said that strategic planning for public relations looks at the various media and communication tactics in their complexity. He categorized communication and media and tactics to highlight their distinctiveness as they relate to the organization using them. He presents an array of communication tactics in four categories: 1) Interpersonal communication offers face-toface opportunities for personal involvement and interaction; 2) Organizational media are published or produced by the organization, which controls the message content as well as its timing, packaging, and distribution; 3) News media provides opportunities for the credible presentation of organizational messages to large audiences; 4) Advertising and promotional media are controlled media, generally external to the organization, that also offer access to large audiences $(2002,174)$. Smith said that each category can be used by hundreds of different communication tactics. Each can be used by organizations to communicate with the public, though not every tool is appropriate for every issue.

Besides, he remembers that people are selective in choosing their communication tools. These communication tactics complement each other. Interpersonal tactics may reach only a few people, but they have a stronger impact on their audiences than any other form of communication. The reverse is true of advertising and promotional media: they can reach out to people in great numbers, but with less impact. The village government has not tried seriously to face opportunities for interaction in RT 03 and RW 01. In addition, key people should motivate residents to create dialogue to stimulate acceptance of the message, an attitude change, and action. The government, meanwhile, focuses on message exposure and massively intensifying accurate dissemination.

Ronald Smith explained strategic planning on how to choose advertising and promotional tactics to publicize its expanded program, as in tactic display advertising in local newspapers $(2002,204)$. Local newspapers, such as Tangsel Pos, reach a number of Bambu Apus residents.

Strategic communication is chosen by the government's executive institution. The legislative and judiciary institution as senders also have their own interests in reaching various kinds of audiences. Why has their strategy not reached the audiences? Were they only concerned with images and projects? On the contrary, the people and public have their own methods for how to manage waste. The sender and receiver are not connected to each other. Both of them should be in agreement over managing waste and saving the earth. In fact, senders and receivers have different ways for how to manage waste and save the earth. This paper will focus on strategic communication applied by legislative, executive, and judiciary institutions for socializing waste management.

\section{THEORETICAL FRAMEWORK}

\section{A. Strategic Communication}

Harold Lasswell wrote that the media performs three major social functions: 1) surveillance of the environment, 2) correlation of different elements of society, and 3) transmission of culture from one generation to text. Ralph E. elaborated the concept of socialization and transmission of culture. Socialization is the process of integrating people within society through the transmission of values, social norms, and knowledge to new members of the group [5].

Further, Hanson described various meanings of socialization: 1) role models in entertainment programming, 2) goals and desires as presented in media content, 3) the citizenship values portrayed in the news, and 4) advertisements for products that may be useful to us in different stages of our lives.

Professor Kirk Hallahan, cited in Dennis L. Wilcox, said that there are various scopes of media and communication tools. The available tools for professionals runs on a spectrum from mass media as public media to one-on-one inter-personal communication. They describe characteristics of media, public media (old media), interactive media (computer-based), and controlled media (annual reports, newsletters, brochures). Then Wilcox and Cameron reiterated James Grunig's point of view that there are five possible objectives for a communicator. DKPP as the government should determine the objectives: 1) message exposure, 2) accurate dissemination, 3) acceptance of the message, 4) attitude change, and 5) change in overt behavior [6]. This paper focuses on message exposure and accurate dissemination.

Professor Kirk Hallahan in Dennis L. Wilcox also pointed out one-way, two-way, and quasi two-way of directions of communication. Newspapers and magazines are one-way. Personal visits, lobbying, and telephone calls are two-way. Web, emails, speeches, exhibits, and demonstration are quasi-two way directions of communication. In reality, Bambu Apus village often only uses one-way.

\section{B. Theory and Model of Communication}

The government as the executive, legislative, and judiciary institutions and the senders use media effectively. They know the different types of mass media and target audience segments. Robert E. Simon has described some advantages and disadvantages of mass media. Some of the advantages of newspapers include their sense of immediacy, local emphasis, and high-fidelity color [7]. Simon explained that media can be identified and defined in terms of demographics as in Tangsel Pos.

Table I-Table II below are communication models according to the communication, development and development-communication theories written by Andi Faisal Bakti in Communication and Family Planning in Islam in Indonesia, 2004. The S M C R E model has a oneway strategy which is all-powerful. Ruben draws a number of conclusions. Aristotle, Lasswell, Schramm, and Berlo emphasized one-way. Shannon-Weaver emphasizes oneway with feedback. Schramm and Wesley-Maclean focus on the circular model through feedback. Dance in Ruben describes the sender and receiver (encoder and decoder of messages) based on previous communication experiences [8].

The convergence model has two ways as strategy but source is crucial. Everett Rogers defined communication as a process in which participants create and share information with one another in order to reach a mutual understanding 
[9]. Key persons should motivate members of mosques and social organizations. Key persons have a subject role as mediators. On the contrary, active-reception is the receiver that constructs the meaning. Source can be removed [10]. Receivers have a subject role, she/he is not the object of the project. Some of them receive the messages while some of them do but deny that they burn waste in daily life.

\begin{tabular}{llc}
\multicolumn{1}{c}{ TABLE I: COMMUNICATION THEORY } \\
\hline \hline $\begin{array}{c}\text { THEORY / } \\
\text { MODEL }\end{array}$ & STRATEGY & $\begin{array}{c}\text { DETERMINANT } \\
\text { FACTOR }\end{array}$ \\
\hline S-M-C-R & One-Way & Source is all-powerful \\
S-M-C-R-E & One-Way & Source is all-powerful \\
$\begin{array}{l}\text { Convergence } \\
\text { Active- } \\
\text { reception }\end{array}$ & $\begin{array}{l}\text { Two-Way } \\
\text { Receiver constructs the }\end{array}$ & $\begin{array}{l}\text { Interaction but source is } \\
\text { crucial }\end{array}$ \\
\hline \hline
\end{tabular}

Andi Faisal Bakti, who deals with development theory, discusses modernization, dependency, multiplicity, and active reception. Modernization has top-down communication and dependency has critique of domination. They support economic development. Multiplicity is participatory or self-reliant. It focuses on economic development and other social factors. Active reception focuses on negotiation among equals. It has the determinant factors of quality of life and emancipation of individuals. How does the government negotiate the bad habits of the RW 01 public in waste management? The government must increase the quality of life through environmental and health literacy.

TABLE II: DEVELOPMENT THEORY

\begin{tabular}{cll}
\hline \multicolumn{1}{c}{ THEORY / } & \multicolumn{1}{c}{ STRATEGY } & \multicolumn{1}{c}{$\begin{array}{c}\text { DETERMINANT } \\
\text { FACTOR }\end{array}$} \\
\hline Modernization & Top-Down & $\begin{array}{l}\text { Supports economic } \\
\text { development }\end{array}$ \\
Dependency & $\begin{array}{l}\text { Critique of } \\
\text { domination }\end{array}$ & $\begin{array}{l}\text { Supports economic } \\
\text { development }\end{array}$ \\
Multiplicity & $\begin{array}{l}\text { Participatory (self- } \\
\text { reliant) }\end{array}$ & $\begin{array}{l}\text { Economic } \\
\text { development and } \\
\text { other social factors }\end{array}$ \\
Active-reception & $\begin{array}{l}\text { Negotiation amongst } \\
\text { equals }\end{array}$ & $\begin{array}{l}\text { Quality of life and } \\
\text { emancipation of } \\
\text { individuals }\end{array}$ \\
\hline \hline
\end{tabular}

An audience is an active reception. They can receive, ignore or deny a message. The rest of them do not care about the 2008 law on burning plastic and other non-organic waste, as in Ranai Town, Natuna, Riau Island (37,6\%) [11] and Manna Town, Bengkulu Selatan (30\%) [12]. Natuna, Manna, and Pamulang Town in South Tangerang have the same problem of burning despite waste management. Based on the facts, the government must have assertive behavior to implement the 2008 law.
In the development and communication theory, Andi Faisal Bakti has discussed diffusion of innovation, social marketing, and participation. Diffusion of innovation focuses on the transfer of technology and social marketing as ideas, processes, and practices through mass media. They are passive. Participation concentrates on the agents' ability to act on their own behalf. Active reception, finally, pertains to the promotion of individuals. They have determinant factors that participation has dynamic interaction between the S-R (through agents of change) factor. Then active reception has meaning that negotiated for emancipation, freedom, and democracy. The government must involve when they are negotiating the 3 Rs (reduce, reuse, and recycle), then lead and force their power over people.

TABLE III: DEVELOPMENT-COMMUNICATION THEORY

\begin{tabular}{|c|c|c|}
\hline $\begin{array}{l}\text { THEORY / } \\
\text { MODEL }\end{array}$ & STRATEGY & $\begin{array}{c}\text { DETERMINANT } \\
\text { FACTOR }\end{array}$ \\
\hline $\begin{array}{l}\text { Diffusion of } \\
\text { innovation }\end{array}$ & $\begin{array}{l}\text { Transfer of } \\
\text { technology }\end{array}$ & Receiver is passive \\
\hline $\begin{array}{l}\text { Social } \\
\text { Marketing }\end{array}$ & $\begin{array}{l}\text { Ideas, processes, } \\
\text { practices through } \\
\text { mass media }\end{array}$ & Receiver is passive \\
\hline Participatory & $\begin{array}{l}\text { Empowerment to act } \\
\text { on their own behalf }\end{array}$ & $\begin{array}{l}\text { Dynamic interaction } \\
\text { between S-R (through } \\
\text { agents of change) }\end{array}$ \\
\hline $\begin{array}{l}\text { Active- } \\
\text { reception }\end{array}$ & $\begin{array}{l}\text { Promotion of } \\
\text { individuals }\end{array}$ & $\begin{array}{l}\text { Meaning is negotiated for } \\
\text { emancipation, freedom } \\
\text { and democracy }\end{array}$ \\
\hline
\end{tabular}

\section{RESEARCH METHODOLOGY}

This research is designed by using a descriptive qualitative approach and constructivism. Data was collected through qualitative content analysis (QCA) from Tangerang Tangsel Pos. DKPP officers, the chief of the administrative village, RW 01 (Rukun Warga [community groups]), RT 03 (Rukun Tetangga [neighborhood groups]), two radio communities, a compost community, and Waste Bank community act as informants in Tangerang Selatan, Banten province, Indonesia.

\section{A. Data Collection Techniques \\ 1) Primary data}

The primary data for this research originates from an indepth interview with the persons representing the legislative and executive institutions. They include firstly Ruhamaben who represented the legislative institution. The executive institutions are represented by the following: DKPP officers Chaerul Sholeh, M. Taher Rochmadi, and Purwanti; the chief administrative village of Bambu Apus Siti Akbari; and the chief of the community group 01 Mahid and 03 Mudatsir. They were interviewed between Sept 9-20, 2013. (see Table IV). This is the hierarchy of government in Tangerang Selatan municipality, Banten Province. The researcher observed Purwanti M.KK from DKKP in socializing waste management through the 3 Rs counseling in Pondok Ranji administrative village on October 4, 2013. The researcher observed Tarmizi Usman as administering the Compost Forum and chief of the $3 \mathrm{Rs}$ bank/trash of 
waste.

\section{2) Secondary data}

The secondary data for this research was qualitative content analysis (QCA) from Tangerang Selatan Post (May-October 2013). To identify the problems encountered by Tangerang Selatan municipality and Tangerang municipality based on the 6 Ms (Man, Material, Money, Machine, Method, and Marketing in managing waste). Literature, documents on members of the Waste Bank and documents of counseling; 3Rss (Reduce, Recycle, and Reuse) in Kelurahan Bambu Apus and Kelurahan Pamulang. Data on waste management was taken from the internet as the secondary data.

\section{B. Validity of Data}

This research applied multiple methods and triangulasi [13] to investigate waste management problems. Take, for example, QCA on Tangsel Post. It is mentioned that the govenrment increased the budget on waste management. The researcher then triangulated the data by observing the 2013 Musrembang annual meeting. Ruhamaben as the legislative institution representative reported that the budget was increased. Furthermore, the researcher also gathered data from the DKPP program with the Korea project in Cipecang through observation and QCA in the local newspaper. A case has been noted in which there was a machine problem where a motorcycle was not running well so Bambu Apus people needed an arm roll. This data is based on observation, photos that were taken and deep interviews with Amsir in Bambu Apus Administrative Village.

\section{Literature Review-Previous Research}

1) The Role of Public Relations of the Ministry of Forestry at the Indogreen Forestry Expo in Jakarta Convention Center 2012, paper by Rofiqoh Wulandari and Linda Islami (Jurnal Ilmu Komunikasi, Avant Garde, vol.1, nomer, July 1, 2013). This paper contributes to introducing a healthy environment to people. The Indo Green Forestry Expo was expected to increase public knowledge and insight about a healthy environment, an awareness of which is still lacking among the Indonesian people.

2) Profiling Environmental Communication Through Text Presented in Media, Anna Agustina, The 3Rsd International Communication Research Conference Proceeding Youth, Media, and Social Change, April 2728, 2012.

Understanding the media text that is presented by the media and consumed by its target will support the understanding of how media constructs the environmental issue and communicates it to the public. The assumption is that if the media text constructs the issue as a criminal text, the result will only be a reaction, not preventive and not using the sustainability concept as a basic understanding. The result will explain the contribution of the media in communicating the environmental issue through its presented text, and relations between environmental communication and social change.

3) Community-Based Waste Management in Studies in Perumahan Semolowaru Bahari Kecamatan Sukolito
Kota Surabaya, Danny Munawar and Taty Alfiah. They have found socialization through family meetings (54\%), special meetings $(21 \%)$, and visiting $(25 \%)$. Governing neighborhood in have motivated them $(25 \%)$, waste manager $(66 \%)$, and mother $(9 \%)$.

4) Relation of Knowledge and Attitude in Waste Management Neighborhood in Environment II, Kecamatan Tumining Kota Menado, North Sulawesi Island, Veita Amelia, B Lampus, A. Tucuman. They found that the possession of knowledge and the consequent attitude were not connected to each other. While mothers know how to manage waste, they do not practice doing so.

5) Implementation of Waste Bank in Waste Management System Kelurahan Gunung Bahagia, Kota Balikpapan, South Kalimantan Island, Asdriyandi, Juliandoni, 2013. They found that the system has not been applied, there is less interest, and there is no plastic sorting. Nobody has been jailed. In addition, the government has been less involved in socialization. Moreover, five cases have revealed that the main problem is that sanctions have been neither addressed nor enforced.

Moreover, it can be assumed that if Indonesia gains literacy ability on the media, environment, health, and law, they will manage waste seriously. Then legislative, executive, and judiciary institutions will be coordinated well. They used the 6 Ms (Man, Money, Machine, Material, Method, Marketing) effectively and efficiently. On the contrary, if Indonesian people do not yet have literacy ability in those fields, they are at a lack of awareness and may pollute the land, water, and air.

\section{FINDINGS}

\section{A. Strategic Communication of the Legislative Institution}

Communicaton strategies employed by senders as well as legislative, executive and judiciary institutions in the waste management of markets in Tangerang Selatan have a lack of coordination. For example, four traditional markets in South Tangerang are under two commands, Tangerang regency and South Tangerang municipality. South Tangerang is a new municipality, a transition from regency to municipality. However, it still uses Tangerang regency facilities. It hasn't reorganized the management of the four traditional markets: Ciputat, Cimanggis, Jombang and Serpong. Actually, based on communiation strategies, senders---legislative, executive and judiciary institutions---should have one command, and thus they need to coordinate.

Legislative and executive institutions hold an annual meeting to ask about RT and RW programs and responses' communication strategies in Bambu Apus administrative village. After Musrembang, an annual meeting of RT and RW is held and they are invited to make a proposal for the annual municipality development. RT and RW, however, do not have access to control. However, despite the important roles of RT and RW as volunteers, they are only involved in the planning stage and have a lack of control in the controlling stage. For example, our RW 01 is still waiting for the government to realize and execute the Waste Bank, legal waste disposal, and street patching programs 
fully.

The former and latest legislators have actually put little concern into environmental issues. The vice legislative institution of South Tangerang (commission 4, budgeting) has not yet executed the planning of waste management 2013, which outlined plans to establish legal landfills and provide two arm rolls for RW 01 Bambu Apus administrative village. In addition, a few candidates from the legislative institution do not consider environmental issues as crucial issues. Similarly, the latest legislator candidates only focused on their banner, neglecting their plan and program to socialize the law of waste management 2008. Based on facts, some members of the commission have not been elected again in 2014, including the chief and his vice (budgeting) of the legislative institution and members from 1999-2014. They have enough room in their budget but less supported capital to seriously commit to green communities.

TABLE IV: HIERARCHY OF EXECUTIVE INSTITUTION OF GOVERNMENT IN INDONESIA

\begin{tabular}{|c|c|c|c|}
\hline No & $\begin{array}{l}\text { Hierarchy of } \\
\text { Government }\end{array}$ & Name of Government & Name of Position \\
\hline 1 & Country & Indonesia & $\begin{array}{c}\text { President Susilo } \\
\text { Bambang Yudhoyono } \\
\text { SBY 2014, Jokowi } \\
\text { 2014-2017 }\end{array}$ \\
\hline 2 & $\begin{array}{l}\text { Provinsi } \\
\text { (Province) }\end{array}$ & Banten & $\begin{array}{c}\text { Governor Ratu Atut } \\
\text { Choisyah }\end{array}$ \\
\hline 3 & $\begin{array}{l}\text { Kabupaten } \\
\text { (Regency) }\end{array}$ & Tangerang & $\begin{array}{l}\text { Regent govt. Officer } \\
\text { Ahmed ZakiIskandar }\end{array}$ \\
\hline 4 & $\begin{array}{c}\text { Kota } \\
\text { (Municipality) }\end{array}$ & Tangerang Selatan & Mayor AirinDiani \\
\hline 5 & $\begin{array}{l}\text { Kecamatan } \\
\text { (Subdistricts) }\end{array}$ & Kecamatan Name: & Camat \\
\hline \multirow[t]{2}{*}{6} & & $\begin{array}{l}\text { 1.Setu } \\
\text { 2.Pondok Aren } \\
\text { 3.Ciputat } \\
\text { 4.Ciputat Timur } \\
\text { 5.Pamulang } \\
\text { 6.Pondok Ranji } \\
\text { 7.Rempoa }\end{array}$ & \\
\hline & Kecamatan & Pamulang & Suhendar \\
\hline 7 & $\begin{array}{c}\text { Kelurahan } \\
\text { (Administrative } \\
\text { village) } \\
\text { RW }\end{array}$ & Bambu Apus & Siti Akbari \\
\hline 8 & $\begin{array}{l}\text { 01(community } \\
\text { group) } \\
\text { RT }\end{array}$ & Rukun Warga & Mahid \\
\hline 9 & $\begin{array}{l}\text { 03(neighbor- } \\
\text { hood group) }\end{array}$ & Rukun Tetangga & Ir. Mudatsir \\
\hline
\end{tabular}

Gans found eight values in the stories he studied: ethnocentrism, altruistic democracy, responsible capitalism, small-town pastoralism, individualism, moderation, order, and leadership. The altruistic democracy is the idea that politicians should serve the public good, not their own interests. This leads to stories that are critical of corrupt politicians [14].

While Airin has done her best, the people who have chosen her---the people and/or constituents---have not supported her program. Constituents are often invited to trainings and workshops, however, they have not applied the knowledge and information that they earned from them in daily life. Why do the constituents not support her? It is because they do not have the means to do so, such as by video and other brochures, banners, stickers, etc. In addition, they have a lack of motivation and appreciation in the community.

Legislative institutions neither encourage nor motivate executive ones to socialize waste management. They also do not support their constituents through magazines, tabloids, or FM or AM radio. Legislative institutions do not motivate judiciary institutions to apply sanctions or to appreciate a green family. These conditions are not only present in South Tangerang. In South Jakarta, for example, the story of Si Pitung Pesanggrahan, Lebak Bulus illustrates the point. Si Pitung, a native of Jakarta and wise local, conducted the 3 Rs activities and made efforts to save Pesanggrahan river in South Jakarta. At first, he was not appreciated neither by the government nor the public. It was only until he was awarded by other countries that people in Indonesia began to appreciate him, such as when he was invited to speak on radio Silaturahmi, 720 AM due to how he could inspire an audience.

\section{B. Strategic Communication of the Executive Institution}

It is mentioned in the 2008 law that there are three ways to manage waste. First, a family must apply the 3Rss: reduce, recycle, and reuse waste at home, including separating organic and non-organic waste. Second, the waste cannot be sold, but rather should be put in legal waste disposal. Third, DKPP must carry the waste to the landfills in Cipecang, South Tangerang.

On the national and local level, communication strategies are manifested in the Adipura Award which is awarded to municipalities, regencies and provinces. Strategic communication earns this award.

Hierarchy of Strategic Communication of Tangsel Local Government in the Layers of South Tangsel Society:

The first layer of communication strategies is conducted through Pesawats. Pesawats is an abbreviation of Pesan Warga Tangerang (The Messages from Tangerang Residents). It is one of Airin's programs in which the residents can convey their complaints regarding public housing via email. The complaints range from smoke toxins (Ciputat Housing), illegal TPS or illegal place of waste disposal (Cempaka Putih Housing), and smoke from waste management (Serua Indah Housing).

Airin has used the old and new media in South Tangerang. The chief of DKKP gives direct solutions on the web for the issue of waste management. This means that only active audiences have access to Pesawats. Thus despite the nature of communication being non-personal, the direction of communication is quasi two-way.

The second layer consists of communication strategies as carried out through local and national television and radio. Nevertheless, DKPP has not yet made use of the means to socialize the law of waste management. For example, RKB (Radio Karya Bersama/community radio), a local cultural radio, played campur sari (mix music) and Radio Karin focused on certain audiences on RT, RW, and kelurahan levels.

Commercial RITS radio in Tangsel should advertise DKPP public counseling consistently. DKPP and local radio should become the role models of waste management through entertainment programs. Radio should reach many 
audiences and thus give waste management more attention and increase public awareness of it.

Communication strategies on the third layer focused on public media. Airin as mayor has asked the public to take pictures of those who throw away garbage in illegal waste disposal areas and send her the picture. This filing of public complaints may be done individually or formally through Pesawats or her new account. Later, Tangsel Pos 2014 informed that she was having difficulities on how to handle the problems and build public awareness as well.

Communication strategies on the fourth layer are conducted through formal DKPP meetings in a kelurahan and every RW held regularly. This activity received a lesser response from the public. Furthermore, the kelurahan has not invited people, based on RT's and RW's representatives in Bambu Apus. Based on the attendance list document, there were 32 members who were not the representatives of RT and RW in Bambu Apus Kelurahan. Based on the data from DKPP, there are supposed to be 50 representatives from the RT and RW levels. The nature of communication of these anniversaries' programming is quasi personal and the direction of communication is quasi two-way.

The fifth layer of communication strategies are conducted through 3Rs demonstrations which are carried out by DKPP regularly. DKPP provide counseling to every administrative village in South Tangerang. DKPP go around kelurahans providing training and workshops. When DKPP holds its 3Rs festival (Gebyar 3Rs), they invite the members of Waste Banks, the sponsorship, and the demonstration held in Pamulang subdistrict. This nature of communication is quasi personal and the direction of communication is quasi two-way. The special meeting is for the members of Waste Bank, not the general public.

The sixth layer of communication strategies is implemented through documents. Based on DKPP documents, there are four categories of Waste Banks in South Tangerang. The first category consists of having routine activities (Ciputat RT04/RW06, Pondok Betung RT 03/RW01, Pondok Karya RW07, Jurang Mangu RW 01, Pondok Aren RW 01, and Pondok Kacang Barat RW 09). Second, Waste Banks have no permanent building. Third, it has a waste management group. And fourth, it has made waste trash proposals but has not executed them yet. According to Tarmizi Usman from KSM Pamulang Mas and Senyum Bumi, the main obstacles of Waste Bank include mafia harga or conspiracy price and thugs in the market.

The documents, annual reports, and brochures of DKPP are included as non-personal and one way. RT and RW do not own brochures of the 3Rss. We can only find them in kelurahan. Furthermore, there were no 3Rs posters in RT 03 and RW 01 given to Bambu Apus administrative village.

Communication strategies on the seventh layer focused on trainings and workshops on the kecamatan and kelurahan levels. Districts and subdistricts often hold trainings. Participants should apply what they have learned in the trainings on the kelurahan level. However, those participants seldom applied 3Rs in their own house. There is no communicator of RW and RT to socialize government policy. On South Tangerang's birthday and on the 85th youth pledge day in October 2013, Siti Akbari as the new village administrator, held activities collecting waste on the street. The Bambu Apus administrative village bought their waste. Siti Akbari disseminated her policy of waste management 2008 in this event.

According to Amsir in kelurahan, they need arm rolls, a small truck, and a big enough budget to manage waste. Amsir said that DKPP should give a part of the budget to RT and RW.

The eighth layer of communication strategies is performed through the Jumat Bersih (clean Friday) movement. The kelurahan regularly visits the RW (neighbors) every Friday. Mahid as RW chief has waited for Jumat Bersih Kelurahan. He noted that it occurred twice a year (December 14, 2012 and June 7, 2013). RW 01 holds the Jumat Bersih program every semester in June and December. The nature of communication of the Jumat Bersih program is quasi personal and the direction of communication is quasi two-way.

However, the program is not responded to well by the residents in RT and RW due to the residents' mobility. For example, residents in a new cluster or tenant members commonly dispose of their waste as they go to work in the morning. They put their garbage on the drainage near the public cemetery. The youth and I tried to take a photo them. We waited for three hours in the morning and at night, yet were still not able to take a photo because they knew that they were being monitored.

Now Kusman is the new chief of RW 01. The RT 01 until RT 07 will take out the trash on the street and do community service (Kerja Bakti) once a month. The green 3Rs movement in RW 01 started the second week of January in 2015. This activity will take place every second week.

For the ninth layer, Mahid carried out participant observation from RW 01 and initiated the monitoring of people passing by carrying parcels of trash every morning (before 6 A.M.) Those people are not responsible for their own waste. They throw it on the edge of the fence. They do not come from RW 01. Perhaps they are from another RW or administrative village.

The tenth layer of communication strategies is undertaken through strategic mapping and appreciation. The results of this research have mapped out how the residents of RT 03 manage their waste. The mapping consists of 5 blue families, 4 green families, 30 yellow families, and 26 red families. We found four categories of how the families understand the 2008 law on managing waste. Based on this fact, RT 03 and Mudatsir have congratulated and thanked the families who have applied the 3Rss principle and who don't burn the plastic in their yard every day. Indications of the research will be discussed in the next paper.

Based on Tangsel Post, the government has policy reports that relate to the departments' program on waste management. Firstly, they suggest that the Social Workforce Department should provide equipment as an effort to manage the waste. Secondly, Human Resources departments should motivate SMA plus (senior high school) to produce fresh water and green cars. The third, the Department of Health's program is Sekolah Sehat (healthy schools) and Prilaku Hidup Sehat dan Bersih/PHSB (Lively, Healthy, Clean, Stable Behavior in Pondok Pakulonan RT 03/RW 04, 
Serpong Utara) (see Table V-Table VI).

TABLE V: LAYERS OF THE EXECUTIVE INSTITUTION IN WASTE MANAGEMENT

\begin{tabular}{|c|c|c|c|}
\hline No & Layers & Name of program & Audiences \\
\hline 1 & National level & Adipura Award & National Highway \\
\hline 2. & Province & Adipura Award & Provincial Highway \\
\hline 3. & Kabupaten & Adipura Award & Local Highway \\
\hline 4. & $\begin{array}{l}\text { Walikota/ } \\
\text { Major }\end{array}$ & Pesawats/web & Active residents \\
\hline 5. & Kecamatan & $\begin{array}{l}\text { How to manage Waste } \\
\text { Banks; Training } \\
\text { Gebyar 3Rs } \\
\text { demonstrations }\end{array}$ & Member of Waste Bank \\
\hline 6. & $\begin{array}{l}\text { Kelurahan } \\
\text { /village }\end{array}$ & $\begin{array}{l}\text { Counseling 3Rss } \\
\text { (Reduce, Reuse, and } \\
\text { Recycle) in annual } \\
\text { meeting. } \\
\text { Festival family walk } \\
\text { Jumat Bersih on } \\
\text { Friday around RW }\end{array}$ & $\begin{array}{l}\text { POKJA is counselor in } \\
\text { the kelurahan }\end{array}$ \\
\hline 7. & $\begin{array}{l}\mathrm{RW} \\
\text { /neighbors }\end{array}$ & $\begin{array}{l}\text { Jumat Bersih on } \\
\text { Friday, every semester } \\
\text { become every month }\end{array}$ & $\begin{array}{l}\text { Personal approach and } \\
\text { watch on passing back } \\
\text { and forth by motor }\end{array}$ \\
\hline 8. & RT /neighbor & $\begin{array}{l}\text { Subscription to } \\
\text { Tangsel Post and } \\
\text { Mapping of Families } \\
\text { in management of } \\
\text { waste }\end{array}$ & $\begin{array}{l}\text { Appreciation on } \\
\text { residents through formal } \\
\text { letters }\end{array}$ \\
\hline
\end{tabular}

TABLE VI :PORTRAYAL IN TANGSEL POS MANAGING WASTE OF SOUTH TANGERANG TOWN AND TANGERANG TOWN

\begin{tabular}{|c|c|c|c|}
\hline No & & South Tangerang Town & $\begin{array}{l}\text { Tangerang } \\
\text { Town }\end{array}$ \\
\hline & $\begin{array}{c}6 \mathrm{Ms} \text { in } \\
\text { Management }\end{array}$ & Airin Diane & $\begin{array}{c}\text { Arief } \mathrm{R} \\
\text { Wismansyah } \\
\end{array}$ \\
\hline 1 & Man & & \\
\hline A & $\begin{array}{l}\text { Public Social } \\
\text { Work }\end{array}$ & $\begin{array}{c}\text { The Hall of KSM } \\
\text { Pamulang }\end{array}$ & \\
\hline B & $\begin{array}{l}\text { Public } \\
\text { Healthy }\end{array}$ & $\begin{array}{l}\text { PHSB clean and } \\
\text { healthy competitive } \\
\text { behaviors } \\
\text { Green and healthy } \\
\text { schools }\end{array}$ & \\
\hline $\mathrm{C}$ & Education & Clean Housing School & Adipura Award \\
\hline $\mathrm{D}$ & BPLH & $\begin{array}{l}\text { Badan Pengelola } \\
\text { Lingkungan Hidup }\end{array}$ & $\begin{array}{l}\text { The law of Air } \\
\text { Pollution }\end{array}$ \\
\hline E & Communities & $\begin{array}{c}\text { PKK/ Wife Community } \\
\text { Restaurants in Serpong } \\
\text { Utara } \\
\text { Friends of Nature } \\
\text { Karang Taruna } \\
\text { KPPPLH Care for } \\
\text { Environment. } \\
\text { PHSB Green behavior } \\
\text { Educate } 3 \mathrm{R} \text { in Pondok } \\
\text { Cabe }\end{array}$ & $\begin{array}{l}\text { Indonesian } \\
\text { Waste } \\
\text { Association } \\
\text { Compost } \\
\text { Forum } \\
\text { Hompima } \\
\text { h (Youth } \\
\text { Forum) }\end{array}$ \\
\hline
\end{tabular}

RT $05 / 05$

F Rubric RT

Ilegal TPS becomes green one in Pondok Cabe Udik

Inspiration of RT in South Tangerang

RT002/RW $05 \quad$ Cempaka Puth

6.5 juta for Trash Bank

Ciputat Timur 15.000

for and 2000 for clean

12 Units of Waste Bank Smelly and

Bank Sampah Airaditas

5 Transportations for

323 meters 2 waste

$15.000 /$ family and 7

million for Waste Bank

$20.000 /$ family for

cleaning service

The budget Tangsel increase

\begin{tabular}{|c|c|c|c|}
\hline 3 & Money & $\begin{array}{c}20.000 / \text { family for } \\
\text { cleaning service } \\
\text { The budget Tangsel } \\
\text { increase }\end{array}$ & \\
\hline 4. & Marketing & Facebook and twitter & $\begin{array}{l}\text { Facebook and } \\
\text { twitter }\end{array}$ \\
\hline 5 & Material & $\begin{array}{l}4000 \text { old and } 1000 \text { new } \\
\text { TPS, } 600 \text { official TPS } \\
\text { and arm-rolls. } 5 \text { trucks } \\
\text { to the last TPS } \\
\text { Installation of fencing in } \\
\text { drainage. } 51 \text { gardens }\end{array}$ & \\
\hline
\end{tabular}

foamy water in

damaging the

pipe

30 trucks

Government Planning

\begin{tabular}{ccc}
\hline Machine & $\begin{array}{c}\text { ITF Intermediate } \\
\text { Treatment Facility } \\
\text { Bunker }\end{array}$ & $\begin{array}{c}3 \text { ton capacity } \\
\text { of trucks } \\
\text { bringing } 5 \text { tons } \\
\text { of waste } 1000 \\
\text { Waste Bank }\end{array}$ \\
& Taking a photo of \\
& Someone who is taking \\
& out the trash \\
& Art Work Waste \\
& Bamboo trees eliminate \\
& odors \\
& 20 Million from Korea \\
& for managing waste \\
\hline \hline
\end{tabular}

Referring to Kirk Hallahan on an integrated public relations media model, South Tangerang government builds public awareness through public media. Radio, tabloids, and magazines have insufficiently portrayed how to manage waste. Interactive media on the web has not yet attracted the public's attention. There are no bulletin boards in RT and RW kelurahan Bambu Apus. The government lets the media control, promote and provide detailed information through video brochures and displays. Demonstrations should be required by the RT and RW levels. South Tangerang government seldom uses one-on-one-visits and lobbying communication to discover audiences who have high involvement. The mapping of families in management of waste is a result of the research; the blue, green, yellow, and red families.

Based on those facts, these tactics earned the Adipura Award. The assessor only examined the main highways, Pesawats' web of South Tangsel (active audiences in housings), counseling 3Rss in kelurahan (not presentative, 50 person audience), 3Rs demonstrations in kecamatan, 
festival program in kelurahan (families in kelurahan Bambu Apus), Jumat Bersih (kelurahan and RW), personal approach of RW 01, and monitoring those passing back and forth by motorcycle and car and throwing waste in illegal waste disposal areas. RT 03 has persuaded and appreciated all residents through formal letters. However, this tactic has not yet been successful for improving people's participation in DKPP's objectives.

The main problem lies with families, schools, and mosques who do not follow the model that we are responsible to follow, that is the 3Rss model. Most residents are not aware that they must apply the 3Rss: reuse, reduce, and recycle in their homes by themselves. The dry waste should be collected and selected, while the wet waste should be composted. Parents, teachers, and preachers neglect early education towards green habits and saving the earth.

According to George E. Belch and Michael A. Belch, the advantanges of newspapers are that they offer high coverage at a low cost, have a short lead time for placing ads, ads can be placed in interesting sections, they are timely, the reader controls exposure, and they can be used for coupons. Disadvantages of newspapers include their short life span, clutter, low attention-grabbing capabilities, poor reproduction quality, and selective reader exposure [15]. DKPP uses a newspaper---Tangsel Pos---to socialize waste management. However, there are only two residents with a subscription to the newspaper.

Based on TangSel newspaper distributor, Musrembangis representative RT and RW dialogue, 2 people subscribe to Tangsel Post in RT 03 and people around the kelurahan administrative village sometimes buy it. The government allocates more budget for various media on the national and local level. On the contrary, human resources, waste management tools, and machines are decreasing. It can be seen that illegal waste disposal and a minimum use of media on the RT and RW levels are mediators to promote and advertise DKPP Tangerang Selatan in balance. RT 03 and RW 01 need videos of water, land, and air pollution as media, posters, and brochures to spread messages in mosques, schools, and neighborhood meetings.

Based on the content of media and non-media, the messages portray to a lesser extent water, air, and land pollution. Messages have a less salient effect in displaying pollution. Cunning defines water pollution and describes the sources and effects of some major types. He defines pollution as any physical, biological, or chemical change in water quality that adversely affects living organisms. There are major water pollutants that cause health problems and ecosystem disruption. He describes examples and sources which demonstrate that they are organic chemicals and inorganic pollutants [16].

Since this research, there has been a change in attitude among members of the mosques. They held during Ramadan a workshop in 2013 with the title Love Allah, Love Human Being, and Love the Environment and another in 2014 entitled Save the Clean Water, Arable Land, and Fresh Air for the kindergarten level until junior school level in Sabilul Muttaqin Mosque. In the workshop, we observe various methods by which we can pinpoint the 3Rss. In fact, in early 2014 there were four green communities: KSM 3Rs RW 01, Senyum Bumi Community in RT 03, Cinta Tanah
Air and Udara (TAU) community in RT 03, and BundaNel group in RT 03. The workshop as strategic communication can be more effective if a family and school continue to apply them in daily life.

Tangsel DKPP government 2014 can promote extensive efforts to make people aware of the 3Rss waste management in our RW 01 and KSM 3Rs. KSM is tentatively TPS before the waste is brought to Cepucang landfill. Cepucang landfill can be overloaded if KSM and green communities do not reduce their waste. MA Kusuma UNS University 2010 has predicted this fate for Sukosari Jumantono Karanganyar landfills, Central Java. The landfills (Tempat Pembuangan Akhir) can no longer accommodate waste.

\section{A. Strategic Communication of the Judiciary Institution}

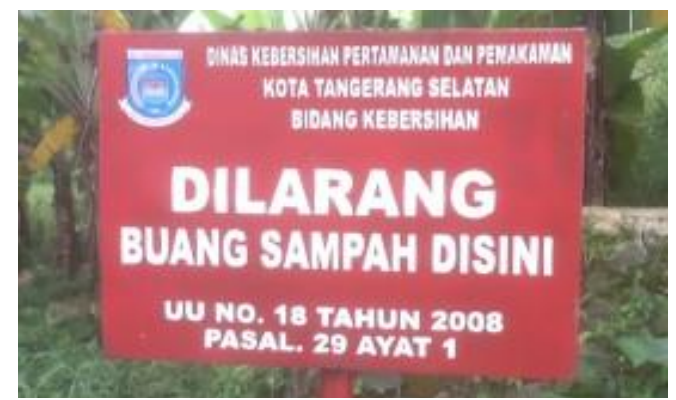

Fig. 1. Do not throw waste here! Law 29, verse 1, number 18, 2008.

The messages of law 29, verse 1, number 18, 2008 imply that residents must separate organic and non-organic waste in order to impede environmental pollution. Governments socialize this law. First, the families must reduce, reuse, and recycle their waste. Second, their waste cannot be sold or composted, but should be placed into a TPS or dumpster. Third, the waste should be brought by truck to a landfill (article 12, verse 1). Cipekang is where the landfill of South Tangerang is located (see Fig. 1).

The 2008 law has sanctions, criminal actions, and standards of waste management which make up article 32 , verse 1 and article 40, verse 1 . Violators never face jail sanctions during 4 to 10 years. Fines are given at a minimal of 100 million and maximal of 5 billion.

The Indonesian government, provinces, and the local governments of kabupatens, walikotas, kecamatans, kelurahans have not reinforced the law seriously. Some local governments have been overseeing the violation, such as in Surabaya and Ponorogo.

People who live in small rented houses are still breaking the 2008 law. Nevertheless, none of them are in jail. People are administering illegal waste disposal in wastelands, drainage, and other areas. In addition, they burn plastic, iron, and tin which causes chemical pollution. People also throw garbage in holes near cemeteries or football yards. Local governments (DKPP and kelurahan) give no reprimand or warning to them. The kelurahan and RW need more Satuan Polisi Pamong Praja (Police Officer Assistants) or at least volunteers to monitor the execution of this policy of the government and halt those who disobey the law.

In Surabaya, Medan, Manado, and Banjarmasin, the government fines people who disobey the 2008 law. Ponorogo mayor has also undertaken this step and South Tangerang mayor will begin to apply the fine as well. SPPP will monitor illegal waste disposal. The people may help 
DKKP and SPPP by taking photos and emailing them to South Tangerang Mayor, thus transforming the people who participate into citizen journalists.

It is clear that waste problems have emerged in modern life. Environmental degradation is one of the most serious problems. This issue has drawn a lot of attention in Indonesia, especially Tangerang municipality, Banten Province. South Tangerang generates about one ton of waste that is sent to a landfill. In fact, Cipekang is the producer of the landfill in Tangsel (The Tangerang Post, 2013). The volume of waste heading to the landfill in Cipekang has increased. We need to overcome this terrible phenomenon. Everybody should participate and take action in reducing waste.

The main solution is not one of giving out fines and warnings or bestowing cultural, sociological, or psychological punishments. The permissive situation in communities has become a problem in the family, in mosques, churches, schools and the market. People believe that waste should be managed by maids, parents, or cleaning services.

Based on Kalvin Coyle's theory, DKPP should review some basic terms and concepts used in media planning and the strategy process. First, media planning is a series of decisions and the guide for media selection. It requires specific media objectives and specific media strategies. Second, the medium is the general category of available delivery system. Third, the reach is the measure of the number of different audience members exposed at least once to a media vehicle in a given period of time. Coverage refers to the potential audience. Finally, frequency refers to the number of times the receiver is exposed to the media vehicle in a specified period [17].

Reduce, reuse, and re-circle waste (3 R) save land, water, and air from pollution in order maintain children's health. Timothy KM Betty and Jay P. Shimshack find marginal increases in carbon monoxide and ground-level ozone are associated with statistically significant increases in children's contemporaneous respiratory treatments. This exposure over has effect on children's health [18].

The government affords to achieve API (air pollution index) below 100 that is blue sky days. The local officials evaluate performance of the number of blue sky days. Dalia Ghanem dan Junjie Zhang find data manipulation and indicate that the official daily air pollution data are not well behaved which suggestive evidence of manipulation. [19]. Government of Chinese cities have done it for image and reputation.

Gokhan Oztruk emphasized the importance of environmental literacy, it should be realized by all member of society regardless of its selection, gender and grade level. Formal education would enable every member of society put their concern on environment in terms of attitude and behavior. Thus, teachers hold a prominent role to create national and global environmental literacy in public [20].

Besides teachers' role, other member of societies should also participate in establishing environmental literacy and also being the role model. Parents, public figures, Majlis taklim (female and male religious community sermons) are some people who would support environmental literacy

We hoped media literacy of executive, legislative, and judicative institutions that they can reach the layers of segments of media but also environmental literacy, ecologicalliteracy and ecoliteracy which diverse is discussed by BB.Mc.Bride et al. As an enrichment, similarities and also differences of those terms would also be elaborated [21].

\section{CONCLUSION}

Strategic communication applied by legislative, executive, and judiciary institutions have a lack of coordination and command agreement in dealing with waste management in South Tangerang. The issue of saving the earth is less popular compared to the other trendy, political issues in the RT (neighborhood group) and RW (community group) level or the bottom most layer.

Family and religious communities are still neglecting the importance of environmental and health literacy. This issue has not been integrated in spiritual communication, Islamic communication, and environmental communication on the national level, not to mention through radio communities and various communities in RTs and RWs on the grassroots level.

Clean government will ensure a balance between man, material, method, machine, marketing, and money. PESAWATS (a website to accept the public's complaints) is the strategic communication applied by the executive institution in South Tangerang. DKPP overlooks layers of RT and RW that need brochures, banners, stickers, CC televisions, trainings, and workshops. It is expected that DKPP will massively provide machines, material/vehicles, and messages. The messages in media should focus on potraying the effects of water pollution, air pollution, and land pollution.

Families, Majlis Taklims (women's informal religious educational centers) and mosques support less the government's program. Furthermore, insufficient appreciation from kelurahans has motivated a "green residents" movement.

The judiciary institution can be in charge of monitoring the 2008 law. The government should work together with residents to establish an observation post in an RT and RW. The residents should take turns to monitor whether or not the violation occured through CCTV.

The legislative, executive and judiciary institutions were not brave and emphatic enough to apply mapping and green card of waste management as strategic communication on RT and RW. The strategy of mapping and green card are recommendation and contribution this research. The government should admonish garbage collectors that undermine the price.

\section{ACKNOWLEDGMENTS}

This work was fully supported by Universitas Islam Negeri Syarif Hidayatullah Jakarta (State Islamic Studies) Fund. Thank you to the Dean and Rector of State Islamic Studies Jakarta who has motivated me to finish this research.

\section{REFERENCES}

[1] S. M. P. Adipura, Airin Kaget di Pasar masih Banyak Sampah, 2014. 
[2] DPRD Tangsel Berhias Wajah Baru, 16 Petahana Bertahan, Tangsel Post, Selasa, vol. 22, 2014.

[3] L. L. Kaid, Political Communication Research, London: Lawrence Erlbaum Associates, 2004, p. 176.

[4] R. D. Smith, Strategic Planning for Public Relations, New Jersey, Lawrence Erlbaum Associates, 2002, p. 155.

[5] R. E. Hanson, Mass Communication, Living in a Media World, New York, Mc. Graw Hill, pp. 26-28.

[6] D. L. Wilcox and G. T. Cameron, Public Relations, Strategies and Tactics, Boston, Pearson Education, 2006, pp. 172-173.

[7] R. E. Simmon, Communication Campaign Management, A System' Approach, New York, Longman, 1990, pp. 137-140.

[8] B. D. Ruben, Communication and Human Behavior, New Jersey: Prentice Hall, 1992, pp.45-46.

[9] E. M. Rogers, Communication Technology, The New Media in Society, London: The Free Press, 1986, p.199.

[10] A. F. Bakti, Communication and Family Planning in Islam in Indonesia: South Sulawesi Muslim Perceptions of a Global Development Program, INIS XLV, Leiden-Jakarta 2004, pp. 39-43.

[11] Jurnal Tata Kota dan Daerah, vol.2, 2, Des 2010.

[12] Naturalis, Jurnal Penelitian Pengelolaan Sumber daya Alam dan Lingkungan, vol. 1, no. 2, 2012.

[13] V. J. Janesick, The Dance of Qualitative Research Design: Metaphor, Methodolatry, and Meaning, California, 1994, Sage Publication, pp. 214-215

[14] H. Gans and R. E. Hanson, Mass Communication, Living in a Media World, New York, Mc. Graw Hill, p. 386.

[15] G. E. Belch and M. A. Belch, Advertising and Promotion, Intergated Marketing Communication Persfective, News York, Mc. Graw Hill, 2004, pp. 301-302.

[16] Cunningham, Saigo, Environmental Science A Global Concern, New York, Mc. Graw Hill Higher Education, 2005, p. 379.

[17] K. Coyle, Environmental Literacy in America, Washington D.C, The National Environmental Education and Training Foundation, 2005, p. 45.
[18] T. K. M. Beatty and J. P. Shimshack, "Air pollution and children's respiratory helath: A cohort analysis," Journal of Environmental Economics and Management, vol. 67, 2012, pp. 39-57.

[19] D. Ghanem and J. Zhang, "Effortless perfection:' Do chinese cities manipulate air pollution data?" Journal of Environmental Economics and Management, vol. 68, 2014, pp. 203-225.

[20] G. Oztruk, "Exploring environmental literacy variables," Journal of Ikogretim-Online, The Journal of Enviromental Education, Elementary Education Online, vol. 13, 2014, pp. 1305-3515,

[21] B. B. M. Bride, Environmentally Literacy, Ecologically, Ecoliteracy: What Do We, 2013.

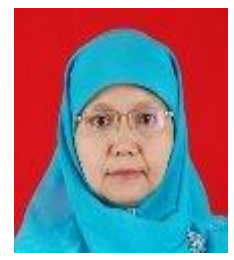

Armawati Arbi was born in West Sumatra, Indonesia in 1965. She received her master's of science in media and communication from the University of Indonesia in 1998. She was granted a Women's Fellowship Award from CIDA to study and participate in a workshop at McGill University in 1997. Publications, International Conference on Women in Indonesian Society Access, Empowerment, and Opportunity; Mass Media and Ideal Women, Jakarta, December 1-4, 1997. The Dissertations Topic: Dakwah through Radio; Social Construction of Radio on Social Reality, Family Counseling Context. 2011. She has been published one paper "Dangdut music as discourse strategies to frame family counseling program in dangdut radio," Jakarta Indonesia, June 26, 2012. Part of this research has been published in the 13th AICIS Annual International Conference on Islamic Studies, Mataram, Senggigi-Lombok Indonesia, November, 18-21, 2013. The topic: Integration of Spiritual Communication, Islamic Communication, and Environmental Communication. Board member of ISKI (Association of Communication Scientists in Indonesia). 